\title{
Upaya Peningkatan Imun Lansia melalui Sleep Hygiene di Panti Sosial Tresna Werda Budi Luhur Jambi
}

\author{
Muhammad Hidayat ${ }^{1}$, Hesty $2^{2}$, Muhammad Azhari ${ }^{3}$ \\ ${ }_{1,2,3}$ Program Studi D3 Keperawatan, STIKes Baiturrahim \\ Email: m.hidayat.immunologist@gmail.com
}

Submitted : 29/01/2021

Accepted: 21/06/2021

Published: 28/06/2021

\begin{abstract}
One of the strategies to increase immunity in the elderly is that the need for sleep is fulfilled in quality and quantity so that it can improve the quality of life of the elderly. The best way to achieve quality and quantity sleep in the elderly is with sleep hygiene. Sleep hygiene is an exercise or habit that can affect sleep. Good sleep hygiene can prevent the development of sleep disorders. Sleep disorders experienced by a person indicate that there is poor sleep hygiene which is caused by a lack of knowledge of the elderly about sleep hygiene so that it has a negative impact on the elderly's immunity. This condition is experienced by the elderly who are in the transcendental social care institution. The tresna werda budi luhur social institution is a partner social institution that has implemented gerontik services according to the program, but in practice there are elderly people who experience poor sleep hygiene. One of the efforts that can be made by the community service implementation team is to provide health education to the elderly. The output of this community service activity is an effort to improve the immunity of the elderly through sleep hygiene. The implementation method used is survey, observation, interview, discussion, and demonstration through health education. This activity was carried out in 12 sessions, attended by 55 elderly people. The result of this activity is conducting health education and awakening the elderly to sleep hygiene and making media through the daily schedule of the elderly with the help of an alarm clock so that the final evaluation of the elderly begins to understand and be aware and able to independently of sleep hygiene. Sleep hygiene is monitored and continued by nurses on duty at the Tresna Wombat Social Home to become a sustainable program.
\end{abstract}

Keywords: immune enhancement, elderly, sleep hygiene

\begin{abstract}
Abstrak
Salah satu strategi peningkatan imun pada lansia adalah kebutuhan tidur yang terpenuhi secara kualitas dan kuantitas sehingga dapat meningkatkan kualitas hidup lansia. Cara terbaik untuk mencapai tidur yang berkualitas dan kuantitas pada lansia adalah dengan sleep hygiene. Sleep hygiene merupakan suatu latihan atau kebiasaan yang dapat mempengaruhi tidur. Sleep hygiene yang baik dapat mencegah berkembangnya gangguan tidur.Gangguan tidur yang dialami seseorang menandakan adanya sleep hygiene yang buruk yang disebabkan karena kurangnya pengetahuan lansia tentang sleep hygiene sehingga berdampak negatif terhadap imunlansia. Kondisi ini dialami lansia yang berada di panti sosial tresna werdha budi luhur. Panti sosial tresna werda budi luhur merupakan panti sosial rekanan yang telah melaksanakan pelayanan gerontik sesuai program, namun dalam pelaksanaannya ada lansia yangmengalami sleep hygiene yang buruk. Salah satu upaya yang dapat dilakukan oleh tim pelaksana pengabdian kepada masyarakat adalah memberikan penyuluhan kesehatan kepada lansia. Luaran kegiatan pengabdian kepada masyarakat ini adalah upaya meningkatkan imun lansia melalui sleep hygiene. Metode pelaksanaan yang digunakan adalah survei, observasi, wawancara, diskusi, dan demonstrasi melalui penyuluhan kesehatan. Kegiatan ini dilakukan dalam 12 sesi, diikuti oleh 55orang lansia. Hasil dari kegiatan ini adalah melakukan pendidikan kesehatan dan menyadarkan lansia untuk sleep hygiene serta pembuatan media melalui jadwal harian lansia dengan bantuan jam alarm sehingga evaluasi akhir lansia mulai mengerti dan sadar serta mampu secara mandiri untuk sleep hygiene. Sleep hygiene dimonitor dan dilanjutkan oleh perawat jaga panti sosial tresna werda untuk dijadikan program berkelanjutan.
\end{abstract}

Keywords: lansia, peningkatan imun, sleep hygiene 


\section{PENDAHULUAN}

Sistem imunitas tubuh memiliki fungsi yaitu membantu perbaikan DNA manusia; mencegah infeksi yang disebabkan oleh jamur, bakteri, virus, dan organisme lain; serta menghasilkan antibodi (sejenis protein yang disebut imunoglobulin) untuk memerangi serangan bakteri dan virus asing kedalam tubuh. Tugas system imun adalah mencari dan merusak invader (penyerbu) yang membahayakan tubuh manusia. Fungsi system imunitas tubuh (immunecompetence) menurun sesuai umur. Kemampuan imunitas tubuh melawan infeksi menurun termasuk kecepatan respons imun dengan peningkatan usia. Hal ini bukan berarti manusia lebih sering terserang penyakit, tetapi saat menginjak usia tua maka resiko kesakitan meningkat seperti penyakit infeksi, kanker, kelainan autoimun, atau penyakit kronik. Hal ini disebabkan oleh perjalanan alamiah penyakit yang berkembang secara lambat dangejalagejalanya tidak terlihat sampai beberapa tahun kemudian. Di samping itu, produksi imunoglobulin yang dihasilkan oleh tubuh orang tuajuga berkurang jumlahnya sehingga vaksinasi yang diberikan pada kelompok lansia kurang efektif melawan penyakit. Masalah lain yang muncul adalah tubuh orang tua kehilangan kemampuan untuk membedakan benda asing yang masuk kedalam tubuh atau memang benda itu bagian dari dalam tubuhnya sendiri.

Salah satu strategi peningkatan imun digunakan pada lansia adalah kebutuhantidur yang terpenuhi secara kualitas dan kuantitas sehingga dapat meningkatkan kualitas hidup. Salah satu cara terbaik untuk mencapai tidur yang berkualitas dan berkuantitas pada lansia adalah dengan sleep hygiene. Sleep hygiene merupakan suatu latihan atau kebiasaan yang dapat mempengaruhi tidur. Sleep hygiene yang baik dapat mencegah berkembangnya gangguan tidur. Gangguan tidur yang dialami seseorang menandakan adanya sleep hygiene yang buruk.

Kebutuhan tidur yang tidak terpenuhiakanmemberikandampakpadafisik maupun psikologis lansia. Dampakfisik yang disebabkan oleh tidakterpenuhinya kualitas tidura dalah peningkatan denyut jantung dan tekanan darah, peningkatan nafsu makandan kadarglukosa, hingga peningkatan hormon stress kortisol. Dampak psikologis yang disebabkan tidak terpenuhinya kualitas tidur diantaranya adalah peningkatan hormon stress kortisol yang menyebabkan penurunan fungsi imunologi, perubahan pikiran yang negative (kontravaktual) dan lebih emosional.

Penelitian sebelumnya yang dilakukan oleh Muhammad Hidayat dengan judul identifikasi sleep hygiene lansia di panti sosial tresna werda budi luhur Jambi ditemukan bahwa karakteristik lansia sebagian besar atau 36 orang lansia $(65,5 \%)$ dari 55 orang berjenis kelamin perempuan. Selanjutnya komponen sleep hygiene lansia berdasarkan skor sleep hygiene indeks terdapat18 orang $(32,7 \%)$ dari 55 orang lansia sering tidur siang hari berlangsung dua jam atau lebih, 18 orang $(32,7 \%)$ dari 55 orang lansia terkadang tidur pada waktu yang berbeda, 18 orang $(32,7 \%)$ dari 55 orang lansia jarang bangun dari tempat tidur pada waktu yang berbeda dari hari ke hari,22 orang $(40 \%)$ dari 55 orang lansia jarang berolahraga sampai berkeringat atau melakukan aktivitas ringan dalam waktu satu jam sebelum tidur, 20 orang $(36,4 \%)$ dari 55 orang lansiajarangberdiam di tempat tidur lebih lama, 49 orang $(89,1 \%)$ dari 55 orang lansia tidak pernah menggunakan alcohol, tembakau, atau kafein dalam waktu empat jam sebelum tidur atau setelah tidur,30 orang $(54,5 \%)$ dari 55 orang lansia tidak pernah melakukan sesuatu yang dapat membuat lansia terjaga sebelum tidur, 37 orang $(67,3 \%)$ dari 55 orang 
lansiatidakpernahtidur dengan perasaan tertekan/stress, marah, kesal/kecewa, atau gugup/cemas, 37 orang $(67,3 \%)$ dari 55 orang lansia tidak pernah menggunakan tempat tidur untuk hal-hal selain tidur, 35 orang $(63,6 \%)$ dari 55 orang lansia tidak pernah tidur di tempat tidur yang tidak nyaman ( misalnya : Kasur atau bantal yang buruk, selimut yang terlalu tebal atau selimut yang terlalu tipis, 31 orang $(56,4 \%)$ dari 55 orang lansia tidak pernah tidur di kamar yang tidak nyaman (misalnya terlalu terang, terlalu pengap, terlalu panas, terlalu dingin, atau terlalu berisik), 30 orang (54,5 $\%)$ dari 55 orang lansia tidak pernah melakukan pekerjaan penting sebelum tidur, 29 orang $(52,7 \%)$ dari 55 orang lansia tidak pernah berpikir membuat rencana atau merasa khawatir ketika lansia di tempat tidur. Sementara Skor sleep hygiene indeks 38 orang $(69,1 \%)$ terkategori baik, 14 orang $(25,45 \%)$ terkategori sedang dan 3 orang $(5,45 \%)$ terkategori buruk.

Dari data penelitian tersebut dapat diketahui bahwa, Panti sosial tresna werda budi luhur provinsi Jambi telahmemberikan pelayanan gerontik sesuai dengantugas dan peran panti sosial tresna werda bagi masyarakat. Namun, pelaksanaan berbagai kegiatan tersebut belum maksimal dan masih memiliki keterbatasan baik dari pihak panti sosial tresna werda maupun masyarakat (lansia) itu sendiri.

Panti sosial tresna werda (PSTW) budiluhur Jambi merupakansatumitra yang memiliki potensi dalam peningkatan imun lansia melalui sleep hygiene di(PSTW) budi luhur Jambi. (PSTW) budiluhur Jambi sudah memiliki keperawatan dan belum mengembangkan fungsinya sesuai dengan kebutuhan PSTW, yaitu fungsi Preventif terhadap kebutuhan sleep hygiene.

Sisi lain, permasalahan mitra yang berkaitan dengan masalah kesehatan dijabarkan sebagai berikut :
Tabel 1.1

Gambaran permasalahan mitra

\begin{tabular}{lll}
\hline No & Masalah kesehatan & Masalah sarana \\
\hline 1. & $\begin{array}{l}\text { Banyaknya lansia yang } \\
\text { belum tau } \\
\text { melakukansleep } \\
\text { hygiene }\end{array}$ & $\begin{array}{l}\text { Belum } \\
\text { maksimalnya } \\
\text { fungsi preventif }\end{array}$ \\
\hline
\end{tabular}

Berdasarkan permasalahan mitra tersebut, dapat diketahui bahwa Panti social tresna werda (PSTW) budiluhur Jambi memiliki dua masalah utama yaitu masalah kesehatan dan masalah sarana. Untuk itu perlu upaya kesehatan yang berbentuk promotif, preventif.

Tim pengabdian masyarakat memberikan fokus pengabdian masyarakat dengan meningkatkan pengetahuan tentang mengaplikasi sleep hygiene bidang promotif. Sedangkan dalam bidang preventif melakukan kegiatan langsung aplikasi sleep hygiene pada lansia.

\section{TARGET DAN LUARAN}

Target dari kegiatan pengabdianini adalah lansia di panti sosial tresna werda budi luhur jambi. Luarannya adalah upaya peningkatan imun lansia melalui sleep hygiene terwujud, sehingga lansia mengikuti jadwal harian yang ditetapkan bersama secara mandiri.

\section{METODE PELAKSANAAN}

Kegiatan pengabdian kepada masyarakat ini dilakukan di Panti sosial tresna werda budi luhur Jambi, selama 3 bulan yaitu 20 September- 20 November 2019. Metode pelaksanaan yang digunakan adalah survey, observasi, wawancara, ceramah, Tanya jawab dan demonstrasi dalam bentuk pemberian penyuluhan kesehatan dan diskusi pembentukan jadwal harian lansia untuk pelaksanaan sleep hygiene. Kegiatan ini dilakukan di ruang tamu wisma lansia masing-masing sebanyak 12 kali pertemuan, diikuti oleh 55 lansia. Materi yang diberikan berbeda-beda pada setiap kali penyuluhan, dengan sebagian peserta yang berbeda-beda juga. Selain mitra dan 
pelaksana, kegiatan ini dibantu oleh beberapa orang mahasiswa Program studi D3 keperawatan STIKes Baiturrahim Jambi.

\section{HASIL DAN PEMBAHASAN}

Kegiatan pengabdian masyarakat di PSTW budi luhur Jambi telah dilaksanakan sesuai dengan yang direncanakan dan kegiatan pengabdian masyarakat ini merupakan tindak lanjut dari saran penelitian oleh muhammad Hidayat yang berjudul Identifikasi Sleep Hygiene Lansia di Panti Sosial Tresna Werda (PSTW) budi luhur Jambi. Dalam pelaksanaan pengabdian masyarakat diperoleh hasil :

1. Sosialisasi informasi mengenai mengaplikasi sleep hygiene pada lansia.

2. Temu dengan lansia

3. Perumusan solusi bersama lansia

4. Pemaparan solusi pada lansia dalam bentuk penyuluhan.

a. Sebelum diberikan penyuluhan, sebagian besar lansia mengatakan tidak paham tentang imun dan dampak yang diakibatkan sleep hygiene yang buruk terhadap imun lansia.

b. Setelah pelaksanaan penyuluhan, beberapa lansia mulai memahami dan aktif bertanya serta mengungkapkan masalah yang dihadapi. Sebagian besar lansia mulai memahami tentang materimateri yang telah disampaikan, banyak yang memberikan pertanyaan dan mengungkapkan pengalaman yang pernah dialaminya saattidur.

c. Sebagian besar lansia menunjukkan sikap positif terhadap pelaksanaan kegiatan penyuluhan.

5. Tindakan langsung:

Menyadarkan lansia untuk sleep hygiene. Mengaktifkan lansia. Memandirikan lansia. Pembuatan
Media (melalui jadwal harian dengan dibantu alarm jam). Evaluasi dan monitoring

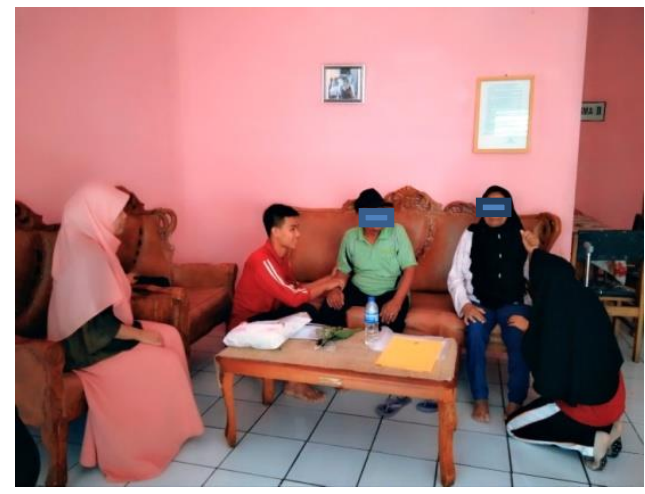

Gambar 1. Penyuluhan kesehatan langsung ke lansia tentang sleep hygiene

Secara umum, seseorang yang berusia 65 tahun keatas merupakan tahap lanjut usia (lansia) dari suatu proses kehidupan yang ditandai dengan penurunan kemampuan tubuh untuk beradaptasi dengan stres lingkungan (Efendi, 2009). Usia 65 tahun adalah awal dari lansia mengalami kehilangan jaringan pada otot, susunan saraf, dan jaringan lain sehingga tubuh mengalami kehilangan sedikit demi sedikit sesuai bertambahnya umur lansia (Nugroho, 2008). Pada lansia terjadi perubahan fisik, mental, psikologi, kognitif, dan spiritual (Mubarak, 2006).

Waktu tidur menurun dengan tajam setelah seseorang memasuki masa tua yaitu usia 65 tahun. Pada proses degenerasi yang terjadi pada lansia, waktu tidur efektif akan semakin berkurang, sehingga tidak tercapai berbagai macam keluhan tidur. Disamping itu juga mereka harus menyesuaikan diri dengan perubahanperubahan secara fisik, fisiologis dan psikologis yang cenderung bergerak kearah yang lebih buruk (Erlina, 2008).

Selain itu juga penuaan menyebabkan perubahan yang dapat mempengaruhi pola tidur. Pada usia lanjut proporsi waktu yang dihabiskan 
dalam tidur tahap 3 dan 4 menurun, sementara yang dihabiskan di tidur tahap 1 meningkat dan tidur menjadi kurang efisien dan kualitas tidur kelihatan menjadi berubah pada kebanyakan lansia (Perri\& Potter, 2005).

Berdasarkan skor sleep hygiene lansia di panti sosial tresna werda budi luhur jambi memberikan informasi bahwa lansia sleep hygiene terkategori baik lebih mendominasi, hal ini bisa disebabkan karena selain terpenuhinya kebutuhan sandang, pangan dan papan lansia adanya kegiatan rutin yang mensejahterakan para lansia yang telah diprogramkan oleh panti sosial misalnya adanya pengajian bersama yang banyak diikuti para lansia di panti sosial tresna werda budi luhur sehingga berdampak banyaknya rasa bersyukur para lansia yang bisa menampung mereka untuk menjalankan kehidupan, dan adanya program terapi rekreasi di panti sosial tresna werda juga berdampak pada sleep hygiene lansia yang baik.

Variasi sleep hygiene lansia di panti sosial tresna werda terkategori sedang bisa disebabkan faktor terkadang lansia tidur pada waktu yang berbeda sehingga berdampak pada terjaga pada waktu yang berbeda pula karena merasa tidurnya belum cukup, faktor lainnya bisa disebabkan latar belakang yang mengharuskan mereka tinggal di panti sosial menjadi pemikiran bagi sebagian lansia berdampak terganggunya tidur lansia. Sementara adanya lansia sleep hygiene terkategori buruk hal ini bisa disebabkan adanya lansia yang sedang menderita penyakit yang menyebabkan terganggunya kebutuhan tidur lansia dan hal ini menjadi perhatian bersama.

\section{KESIMPULAN DAN SARAN}

\section{Kesimpulan}

Sebagian besar lansia memahami bagaimana sleep hygiene, lansia juga mengikuti jadwal harian yang ditetapkan bersama secara mandiri.

\section{Saran}

Diharapkan kepada kepala UPTD beserta petugas panti sosial tresna werdha agar selalu memotivasi kepada lansia untuk melakukan sleep hygiene setiap hari.

\section{UCAPAN TERIMAKASIH}

Semua tim dan mitra pada kegiatan pengabdian ini mengucapkan terimakasih kepada Kepala Dinas sosial, kependudukan dan pencatatan sipil provinsi Jambi beserta jajarannya, Kepala UPTD PSTW "Budi Luhur" besertajajarannya, Mitra dari Panti sosial tresna werda budi luhur Jambi terutama penanggung jawab dan pelaksana kegiatan penyuluhan, Ketua STIKes Baiturrahim Jambi beserta jajarannya yang telah membantu dalam bentuk dukungan moril dan materil kegiatan pengabdian kepada masyarakat ini, Mahasiswa Program Studi D3 Keperawatan STIKes Baiturrahim Jambi, Semua pihak yang membantu terlaksananya kegiatan ini.

\section{DAFTAR PUSTAKA}

Azizah, Lilik Ma'rifatul. (2011). Keperawatan Lanjut Usia, Ed.1. Graha Ilmu. Yogyakarta.

Fakihan A. Hubungan Aktivitas Fisik dengan Kualitas Tidur Pada Lanjut Usia. 2016.Universitas Muhammadiyah Surakarta;

Irish LA, Kline CE, Gunn HE, et al. The role of sleep hygiene in promoting public health: A review of empirical evidence. Sleep Med

Rev 2015;22:23-36. [PMC free article] [PubMed] [Google Scholar]

Lacks P, Rotert M. Knowledge and practice of sleep hygiene techniques in insomniacs and good sleepers. Behav Res Ther 1986;24:3658. [PubMed] [Google Scholar] 
Mastin DF, Bryson J, Corwyn R. Assessment of sleep hygiene using the Sleep Hygiene Index. J Behav Med 2006;29:223-7. [PubMed] [Google Scholar]

Nam S, Whittemore R, Jung S, et al. Physical neighborhood and social environment, beliefs about sleep, sleep hygiene behaviors, and sleep quality among African Americans. SleepHealth 2018;4(3):2 58-64. [PMC free article] [ PubMed] [Google Scholar]

Notoatmodjo, S. 2012. Promosi Kesehatan dan Perilaku Kesehatan. Jakarta: PT Rineka Cipta.

Padila. 2013. Buku Ajar Keperawatan Gerontik. Numed. Yogyakarta

Yang CM, Lin SC, Hsu SC, et al. Maladaptive sleep hygiene practices in good sleepers and patients with insomnia. $J$ Health Psychol 2010;15:147-

55.[PubMed] [Google Scholar] 